DE

M E D I C I N A

T R O P I C A L

$\mathrm{DE}$

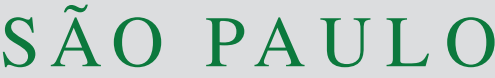

JOURNAL OF THE SÃO PAULO INSTITUTE OF TROPICAL MEDICINE

\section{Soil contamination of a public park by human and canine mastadenovirus, as well as hookworms and Toxocara spp eggs}

\author{
Ana Karolina Antunes Eisen ${ }^{(1)}$, Meriane Demoliner ${ }^{(\mathbb{1})}$, Kelen Gras de \\ Oliveira ${ }^{(1}$, Eduardo Artur Troian ${ }^{(1)}$, Larissa Mallmann ${ }^{(1)}$, Micheli Filippi ${ }^{\left({ }^{1} 1\right.}$, \\ Paula Rodrigues de Almeida ${ }^{\circledR}$, Fernando Rosado Spilki ${ }^{\circledR 1}$
}

\section{ABSTRACT}

Public parks are leisure environments widely used by both, adults and children, often accompained by their pets. Soil contamination of these environments by enteric viruses and intestinal parasites occurs through these animals feces. The aim of this work was to detect Carnivore protoparvovirus 1 (CPV-1) and different species of Mastadenovirus in soils samples from a park located in a medium-sized city in Brazil and evaluate the presence of helminth eggs and larvae in 18 points of a public park soil samples, as well as feces found on this site during six months. Parasitological analyzes were conducted through flotation and sedimentation techniques, and polymerase chain reaction (PCR) was used for viral detection. Of the 216 soil and 16 feces samples, 49\% (106/216) and 12\% (2/16) were positivefor nematodes larvae, respectively, through sedimentation techniques. Toxocara spp eggs were found in one soil sample and one feces sample, Trichuris spp eggs were found in only one feces sample and Hookworms eggs were found in four soil samples. After reconstruction work in the streets near the park, 30\% (64/216) of the samples were positive for Human Mastadenovirus C (HAdV-C), 1.4\% (3/216) for HAdV-E and 0.4\% (1/216) for Canine Mastadenovirus A (CAdV-A). The parasitic forms found in this study have demonstrated that the contamination of the park's soil pose a threat to human and animal health. This was the first study to report the presence of HAdVs and CAdVs in soil samples.

KEYWORDS: Park soil. Soil contamination. Microbial contamination. Mastadenovirus. Hookworm. Toxocara. Hookworms.

\section{INTRODUCTION}

Public parks are leisure environments widely used by both, adults and children, often accompained by their pets making these environments exposed to human and animal viruses and intestinal parasites through soil contamination by pets and stray dogs' feces ${ }^{1}$. Bearing this information in mind, animal helminths, larvae as well as infecting eggs may be present in the soil of parks giving rise to clinical manifestations related to infections caused by cutaneous larva migrans (CLM - caused by Hookworms), visceral larva migrans (VLM) and ocular larva migrans (OLM caused by Toxocara canis and T. cati $)^{2,3}$. Along with parasites, enteric viruses, such as members of Adenoviridae and Parvoviridae families, can also be detected in contaminated soil and can cause infections when ingested, as these pathogens are transmitted by fecal-oral route and they can maintain infectivity for long periods in the environment $^{4,5}$. Furthermore, these viruses are usually species-specific, traits that make 
them useful for tracking down the source of contamination. When ingested, they can cause gastroenteritis, among other manifestations that can kill puppies ${ }^{6}$. Therefore, it becomes relevant to survey these pathogens in parks, taking into account both, human and animal welfare.

Several studies have already reported soil contamination of parks and squares with helminths such as Toxocara spp, Ancylostoma $\mathrm{spp}$ and Trichuris $\mathrm{spp}^{7-11}$. However, there have not been studies on soil contamination of parks by adenoviruses or parvoviruses so far. The aim of this study was to evaluate the presence of Canine mastadenovirus $A$ (CAdV-A), Carnivore protoparvovirus 1 (CPV-1), different species of Mastadenovirus from mammals, including humans (HAdV) and helminths' eggs and larvae in the soil of an area designated for animal' recreation as well as a children's playground in a public park, in the city of Novo Hamburgo (Brazil) for a period of six months.

\section{MATERIALS AND METHODS}

\section{Studied area}

The studied area was a newly founded public park in the city of Novo Hamburgo, Southern Brazil, opened about a year before the first sampling. The park has a children's playground composed of a sandbox and a fenced area intended for dogs' recreation. Altogether, eighteen sampling points were chosen; nine in the children's playground and nine in the area for dogs' recreation. The sampling points are shown in Figure 1.

\section{Sample collection}

Samplings were performed fortnightly during the period of March to August 2018, always on Mondays. Fifty grams of soil were sampled superficially from an area of $10 \mathrm{~cm}^{2}$ using a $50 \mathrm{~mL}$ Falcon tube, and when dogs' feces were present, they were sampled as well. Samples were transported to the Laboratory of Molecular Microbiology (LMM) and immediately processed for parasitological analyses. Aliquots of samples were stored in a ultrafreezer $\left(-80^{\circ} \mathrm{C}\right)$ for posterior detection of viral genomes.

\section{Parasitological analyses}

A sedimentation technique was performed with $10 \mathrm{~g}$ of soil samples or $5 \mathrm{~g}$ of feces dissolved in $200 \mathrm{~mL}$ of ultrapure water; after dissolution of the samples, they were filtered with parasitological filters and stayed still for $24 \mathrm{~h}$ until the slides preparation and analysis under an optical microscope. In addition, a flotation technique was used, starting with $10 \mathrm{~g}$ of soil samples or $5 \mathrm{~g}$ of feces dissolved in $17 \mathrm{~mL}$ of saturated sodium chloride solution $(\mathrm{NaCl})$ and then filtered with a parasitological filter. Afterwards, they stayed still for $30 \mathrm{~min}$ with a slide on the top, then the slide was removed and samples were analysed under an optical microscope ${ }^{12}$. Each sample was analyzed twice by the spontaneous sedimentation technique.

\section{Sample preparation and genomic DNA extraction}

One gram of each sample was mixed with $1 \mathrm{~mL}$ of Eagle's Minimum Essential Medium (Sigma-Aldrich, Buchs, Swizerland) pH 11.0 and the mixture was homogenized in a vortex for $1 \mathrm{~min}$. After that, samples were incubated for $1 \mathrm{~h}$ under refrigeration and then genomic DNA extraction was carried out ${ }^{13}$ with the ReliaPrep ${ }^{\text {TM }}$

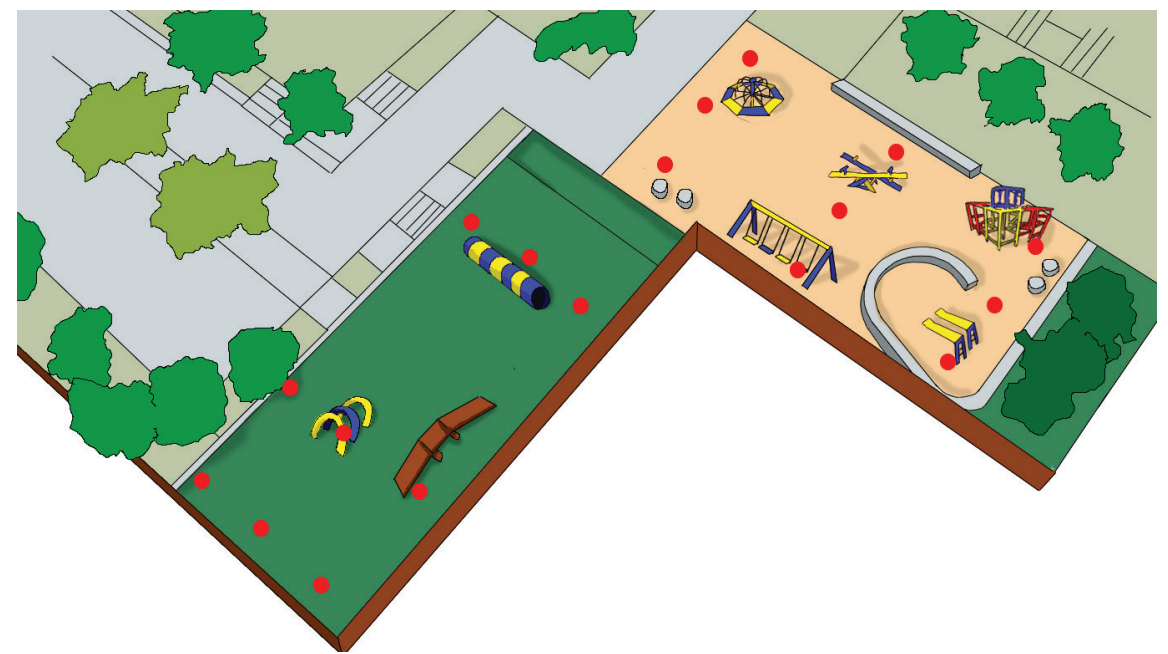

Figure 1 - Illustration of the park where the study was carried out. The red points show the places where the samples were taken in the children's playground and in the animal's recreation area. 
Blood gDNA Miniprep System (Promega ${ }^{\circledR}$, Madison, USA), following the manufacturer's instructions.

\section{Viral genome detection}

Polymerase chain reaction (PCR) was used for detecting viral genomes: reactions were made in a final volume of $50 \mu \mathrm{L}$, being $5 \mu \mathrm{L}$ of DNA sample, $25 \mu \mathrm{L}$ of the PCR Mix solution (Promega ${ }^{\circledR}$, Madison, USA), $18 \mu \mathrm{L}$ of RNA-DNAse free water and $1 \mu \mathrm{l}$ of each primer. CAdV-A amplification started with an initial denaturation step of $98^{\circ} \mathrm{C}$ for $7 \mathrm{~min}$, followed by 35 cycles of $1 \mathrm{~min}$ at $94^{\circ} \mathrm{C}, 1 \mathrm{~min}$ at $54^{\circ} \mathrm{C}$ and $1 \mathrm{~min}$ at $72{ }^{\circ} \mathrm{C}$, and a final extension of $7 \mathrm{~min}$ at $72{ }^{\circ} \mathrm{C}^{14}$. CPV-1 amplification started with an initial denaturation step started at $95^{\circ} \mathrm{C}$ for $5 \mathrm{~min}$ followed by 35 cycles of $30 \mathrm{~s}$ at $95{ }^{\circ} \mathrm{C}, 30 \mathrm{~s}$ at $50{ }^{\circ} \mathrm{C}$ and $1 \mathrm{~min}$ at $72{ }^{\circ} \mathrm{C}$, followed by a final extension step of $7 \mathrm{~min}$ at $72^{\circ} \mathrm{C}^{15}$. For AdVs genomic detection, a nested-PCR was performed as follows: an initial denaturation step at $94^{\circ} \mathrm{C}$ for $5 \mathrm{~min}$ followed by 40 cycles at $94{ }^{\circ} \mathrm{C}$ for $30 \mathrm{~s}, 50^{\circ} \mathrm{C}$ for $30 \mathrm{~s}$ (decreasing $0.5^{\circ}$ per cycle) and $72{ }^{\circ} \mathrm{C}$ for $1 \mathrm{~min}$ and then a final extension step at $72{ }^{\circ} \mathrm{C}$ for $10 \mathrm{~min}^{16}$. Viral nucleic acids extracted from a comercial canine vaccine (Vanguard $^{\circledR}$, Zoetis Inc.) were used as positive controls and RNAse/DNAse free water was used as the negative control. The sequence of primers used in all the reactions are detailed in Table 1.

\section{Sequencing of the samples}

Positive samples were purified with the PureLink ${ }^{\mathrm{TM}}$ Quick Gel Extraction kit and the PCR Purification Combo Kit (Invitrogen ${ }^{\mathrm{TM}}$, Thermo Fisher Scientific, Waltham, MA, USA) and sent for sequencing. Contigs were edited by the BioEdit alignment editor (Ibis Therapeutics, Carlsbad, CA, USA) and the phylogenetic analysis was performed by the Mega X software (MEGA Software, Pennsylvania, USA) through a phylogenetic tree construction using the Neighbor-Joining method and the Kimura 2 model (MEGA Software, Pennsylvania, USA).

\section{RESULTS}

From March to August 2018, 216 soil samples and 16 feces samples were collected. The first sampling that took place in March was the one with the lowest rate of positive samples; this sampling was carried out on a dry and hot day with intense sun. The next two samplings were performed on rainy days, and it was possible to notice a considerable increment in the number of larvae-positive samples and more larvae were seen on samples slides as well. Thenceforth, the frequencies were variable however, it was observed that the animal recreation area was more often contaminated. Two feces samples were also larvaepositive. Detection of nematode larvae according to the samplings is shown in Figure 2.

Trichuris spp eggs were detected in only one feces sample; Hookworms and Toxocara spp eggs were detected in soil samples of the children's playground and the animal recreation area, respectively. Toxocara spp eggs were also directly detected in feces samples. The flotation technique was performed with samples from the fourth sampling and results of parasitological analyses are detailed in Table 2, where it is possible to see the larvae and eggs found by using each of the techniques. The parasitic forms found during microscopy are seen in Figure 3.

Concerning the viral analysis of the samples, none were positive for CPV and only one soil sample from the ninth sampling (July/2018) was positive for CAdV-A. However, for AdVs, the first three samplings were negative, but from the fourth (April/2018) on, an average 73\% of the soil samples were positive until the ninth sampling, coinciding with the beginning of reconstruction work carried out in the streets that circumvent the park, and the last three samplings presented only $5.4 \%$ positivity on average for AdVs. These results are shown in Figure 4. Positive samples for HAdVs formed clusters in the phylogenetic tree, mainly with HAdV-C, 9 of them feces samples; three soil samples were clustered with HAdV-E and the only positive sample for CAdV was clustered in the CAdV type 2 clade (Figure 5).

Table 1 - Sequences of primers used in viral genome detections.

\begin{tabular}{|c|c|c|c|}
\hline & Primer forward & Primer reverse & Reference \\
\hline CAdV-A & $\begin{array}{c}\text { CAV-F1 } \\
\text { 5'-CACGATGTGACCACTGAGAG-3' }\end{array}$ & $\begin{array}{c}\text { CAV-R1 } \\
\text { 5'-GGTAGGTATTGTTTGTGACAGC-3 }\end{array}$ & Monteiro et al. ${ }^{14}$ \\
\hline CPV-1 & $\begin{array}{c}\text { CPV-555-for } \\
\text { 5'-CAGGAAGATATCCAGAAGGA-3 }\end{array}$ & $\begin{array}{c}\text { CPV-555-rev } \\
\text { 5'-GTGCTAGTTGATATGTAATAAACA-3' }\end{array}$ & Buonavoglia et al..$^{15}$ \\
\hline AdV & $\begin{array}{c}\text { Pol-F } \\
\text { 5'-CAGCCKCKGTTRTGYAGGGT-3 }\end{array}$ & $\begin{array}{c}\text { Pol-R } \\
\text { 5'-GCHACCATYAGCTCCAACTC-3' }\end{array}$ & \multirow{2}{*}{ Li et al. ${ }^{16}$} \\
\hline AdV-Nested & $\begin{array}{c}\text { Pol-nF } \\
\text { 5'-GGGCTCRTTRGTCCAGCA-3' }\end{array}$ & $\begin{array}{c}\text { Pol-nR } \\
\text { 5'-TAYGACATCTGYGGCATGTA-3' }\end{array}$ & \\
\hline
\end{tabular}




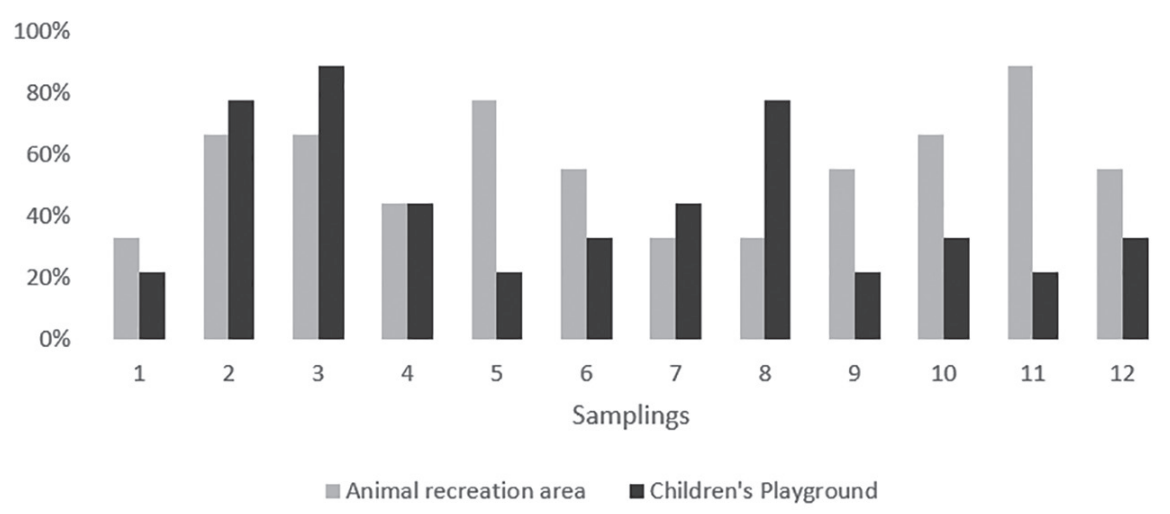

Figure 2 - Frequency of positive samples for nematode larvae in the children's playground and in the animal's recreation area according to the sampling.

Table 2 - Results of parasitological analyses according to the techniques used to evaluate soil samples and feces samples.

\begin{tabular}{|c|c|c|c|c|}
\hline \multirow{3}{*}{ Parasites } & \multicolumn{4}{|c|}{ Parasitological techniques } \\
\hline & \multicolumn{2}{|c|}{$\begin{array}{l}\text { Flotation* } \\
\mathrm{N}(\%)\end{array}$} & \multicolumn{2}{|c|}{$\begin{array}{c}\text { Sedimentation } \\
N(\%)\end{array}$} \\
\hline & Soil & Feces & Soil & Feces \\
\hline Total analysed & 162 & 11 & 216 & 16 \\
\hline Larvae & $6(4 \%)$ & ND & $106(49 \%)$ & $2(12 \%)$ \\
\hline Hookworm egg & $4(2 \%)$ & ND & ND & ND \\
\hline Toxocara sp. & $1(0.5 \%)$ & $1(9 \%)$ & ND & ND \\
\hline Trichiuris sp. & ND & $1(9 \%)$ & ND & $1(6 \%)$ \\
\hline
\end{tabular}

* The Flotation technique presents a lower number of samples because the first three samplings were not analysed by this technique; $\mathrm{N}=$ Number of samples; ND = Not detected.

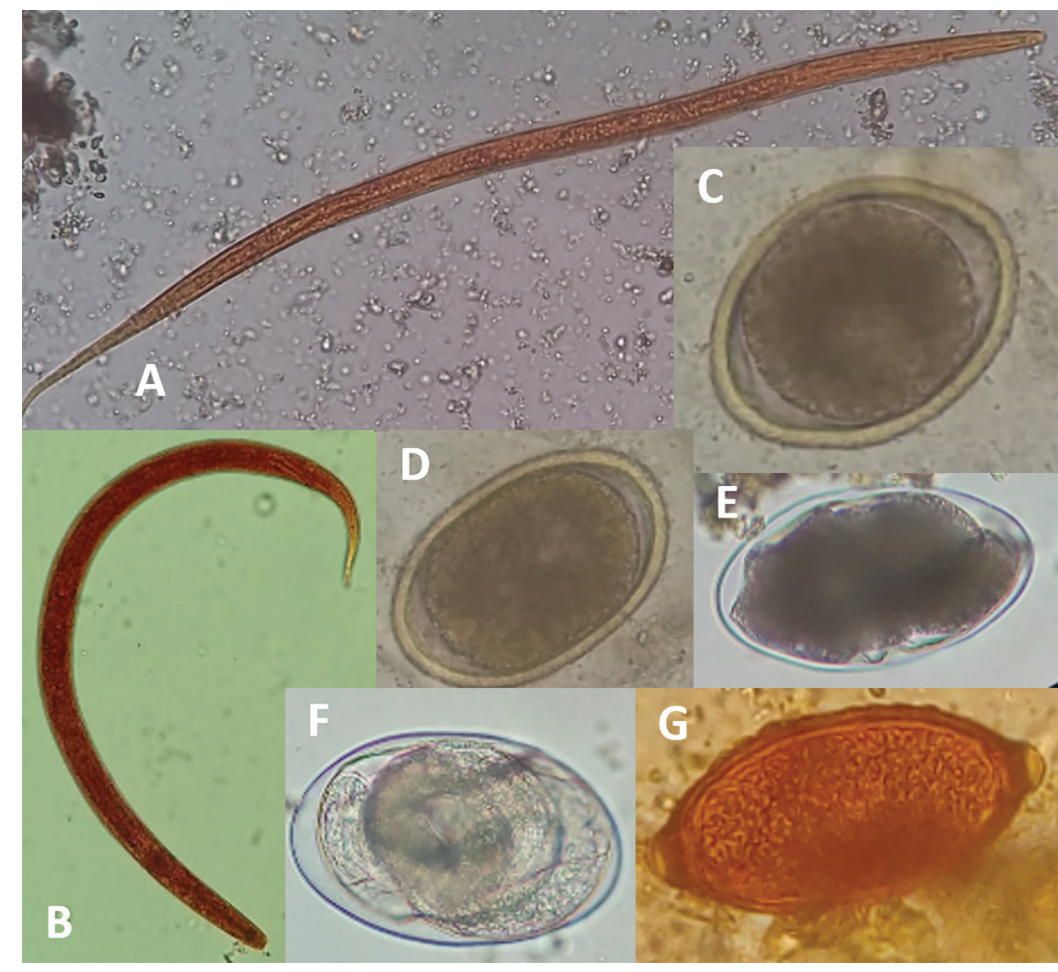

Figure 3 - Parasitic structures found on microscopy. A and B: nematode larvae; C and D: Toxocara spp eggs; E and F: Hookworm eggs; G: Trichiuris spp egg 


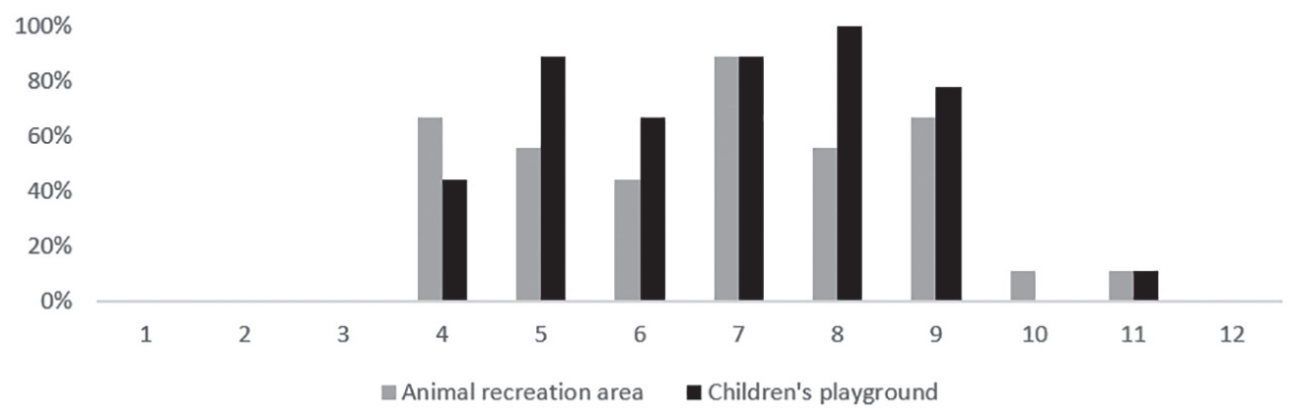

Figure 4 - Positive frequency of soil samples for AdVs according to the sampling.

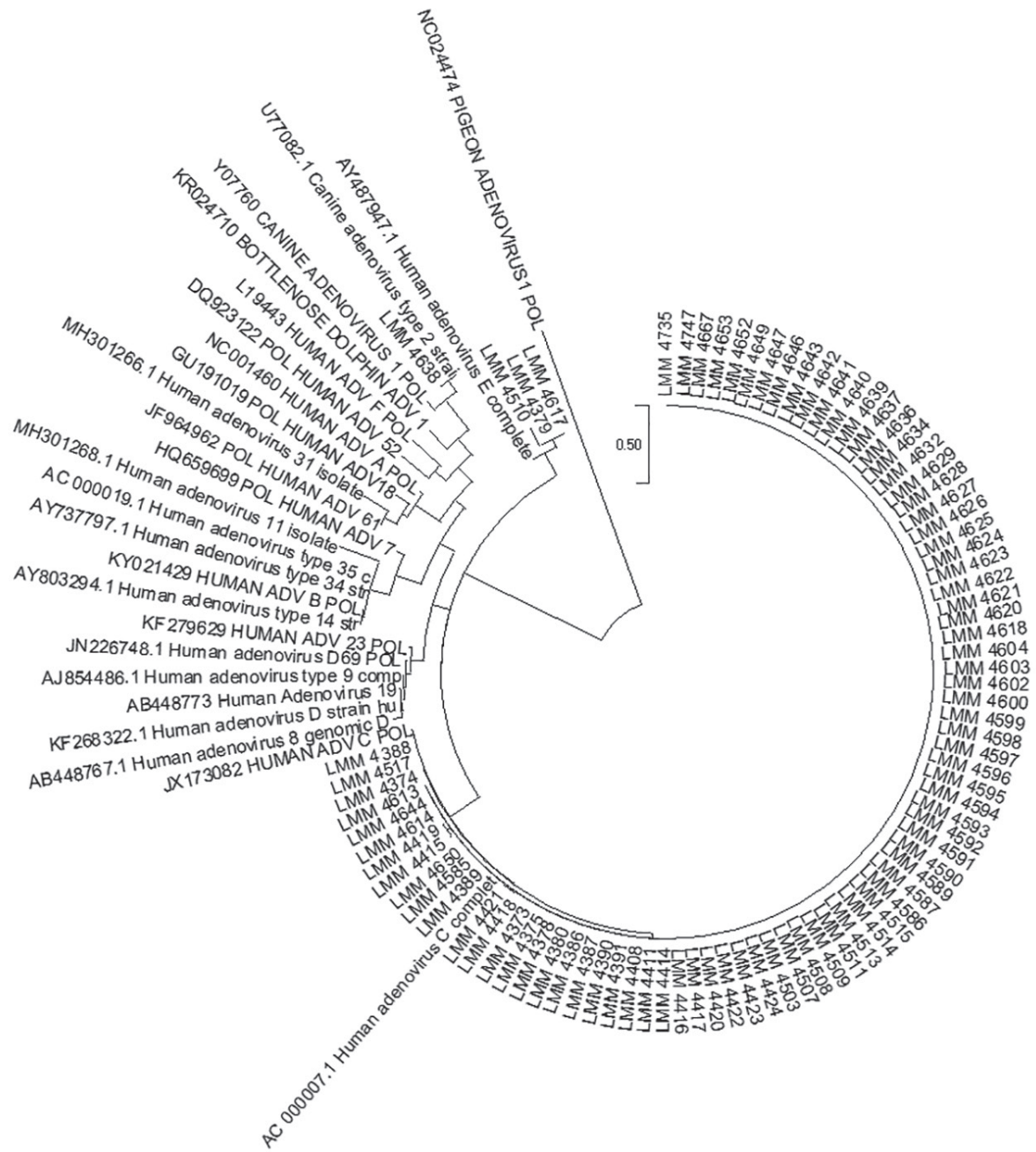

Figure 5 - Phylogenetic tree of ADV-positive samples by the Neighbor-Joining method with the Kimura-2 model.

\section{DISCUSSION}

This study sought for the first time to analyse larvae and eggs of helminths together with enteric viruses as AdVs and CPV in soil samples of a public park, both in the children's playground and in the animal recreation area. Taking into account that samples were collected during six months, it was possible to follow the contamination of the soil throughout this period.
In relation to the parasitological analysis, through the flotation technique it was possible to detect the contamination of the soil by Hookworms and Toxocara spp eggs, and the last one was only detected in the children's playground. Some of the feces samples were also positive for Trichuris spp and Toxocara spp eggs. Moreover, there was positivity for nematode's larvae present in most of the soil samples corroborating the findings of other similar studies ${ }^{7,17}$, in both, the children's playground and the animal 
recreation area. Unlike eggs, larvae detection occurred mainly through the spontaneous sedimentation technique. In the same way, the presence of Hookworm and Toxocara spp eggs in soil samples of public parks has already been reported in other similar works ${ }^{7,11,18,19}$.

The first sampling showed the lowest frequency of larvae-positive samples, fact that can be explained because sampling was carried out in a hot and dry day of Summer with an intense sun, which may have damaged parasitic structures or caused their migration to lower layers of the soil. In the next two samplings, it was raining and that may have contributed to the increment of positive samples. In the following samplings, frequencies were mantained higher due to mild temperatures and to higher moisture ${ }^{20}$.

The presence of parasitic structures in parks' soil poses a threat to people who might get in contact with contaminated soil, being the children the most susceptible due to a higher exposure of their skin directly in contact with contaminated soil when they play in this environment. The nematode larvae found in this study were not identified, but given the presence of Hookworm eggs in some samples, at least some of these larvae may be Hookworm larvae that hatched from the eggs to the soil, pointing out the risk of contracting CLM, caused by infective larvae of these helminths that are present in the soil ${ }^{21}$. Similarly, VLM and OLM could be transmitted mainly through the ingestion of embrionated eggs of Toxocara spp present in the soil. Therefore, the presence of parasitic structures detected in this study confirms that people who attend this place are at isk $^{22}$.

In relation to the detection of $\mathrm{AdVs}$ in the soil during the first three samplings, viral genome was not detected, however, in the fourth sampling, more than a half of the samples were virus-positive; this increment of viral detections coincided with pipe replacement renovations carried out on the streets around the park. Contamination that has started in the fourth sampling, may be due to the soil shuffling during reconstruction work and to the exposure of old pipes that have been removed. Even if the pipes changed were of treated water, it has been demonstrated that AdVs are present in treated water in the study carried out by Kluge et al. ${ }^{23}$, and rain falls could help to spread viral particles in the sand of the children's playground and in the park's soil.

Concerning the AdVs diversity found in this study, only one sample from the animal's recreation area was identified as CAdV. The low frequency of CAdV in the samples and the absence of CPV may be related to the fact that the majority of the dogs that frequent the place are vaccinated. The majority of positive samples belongs to group C Human Mastadenovirus (HAdV) and three samples to group E, and both groups are commonly found in sewage as well as in superficial water samples ${ }^{24-27}$.

The contamination found in this study remained from April to July and decreased in the last three samplings. This can be explained by a possible inactivation of viral particles present on soil surface due to solar radiation and UV lights. In the study carried out by Schwarz et al..$^{28}$, it was demonstrated that AdVs resist for 180 days or even more in a soil consisting of biosolids, however, the surface was protected from UV lights because wheat plantations were present on the site, besides that the experiment was carried out during Winter, when the soil temperature did not exceed $20^{\circ} \mathrm{C}$. Thus, in the soil and in the sand of the park exposed to solar radiation and with the soil's temperature being possible higher, AdVs could resist through a shorter period. The amount of rain might have influenced, making it easier to viral particles to infiltrate in the deeper layers of the soil ${ }^{29}$. Corroborating with this hypothesis, the last three samplings were performed in sunny days, while the two previous were carried out in rainy days. However, more researches are required about enteric viruses in soil for the better knowledge of the behaviour of these microrganims in this type of environment.

\section{CONCLUSION}

The presence of Hookworms and Toxocara spp eggs and nematode's larvae shows that fecal contamination is occuring in this park and poses a threat to the health of humans and animals. More effective efforts should be taken to avoid soil contamination with intestinal parasites, mainly in the children's playground.

This was the first report on the presence of HAdVs and CAdVs in soil samples of a park contributing to understand the dinamics of enteric viruses in soil samples, even though more studies in this field are needed.

\section{CONFLICT OF INTERESTS}

The autors declare no conflict of interests.

\section{ACKNOWLEDGEMENTS}

FR Spilki is a fellow of the Conselho Nacional de Desenvolvimento Científico e Tecnológico - CNPq. AKA Eisen is recipient of a master scholarship of the Coordenação de Aperfeiçoamento de Pessoal de Nível Superior-CAPES. The authors are grateful for the financial and structural support from Universidade Feevale, the CAPES, CNPq and the Fundação de Amparo à Pesquisa do Estado do Rio Grande do Sul - FAPERGS. 


\section{AUTHORS' CONTRIBUTIONS}

Ana Karolina Antunes Eisen: sampling, sample preparation, microscope analysis, extractions, molecular detection and writing; Meriane Demoliner: sampling, sample preparation, microscope analysis, molecular detection; Kelen de Oliveira Gras: sample preparation, microscope analysis, purification and pre-sequencing work; Eduardo Artur Troian: sample preparation, microscope analysis; Larissa Mallman: sample preparation, microscope analysis; Micheli Filippi: sample preparation, microscope analysis; Paula Rodrigues de Almeida: phylogenetic tree construction, theoretical orientation of parasitology, text revision; Fernando Rosado Spilki: guidance, writing and text correction.

\section{REFERENCES}

1. Traversa D, Frangipane di Regalbono AF, Di Cesare A, La Torre F, Drake J, Pietrobelli M. Environmental contamination by canine geohelminths. Parasit Vectors. 2014;7:67.

2. Heukelbach J, Feldmeier H. Epidemiological and clinical characteristics of hookworm-related cutaneous larva migrans. Lancet Infect Dis. 2008;8:302-9.

3. Strube C, Heuer L, Janecek E. Toxocara spp. infections in paratenic hosts. Vet Parasitol. 2013;193:375-89.

4. Bosch A, Pintó RM, Abad FX. Survival and transport of enteric viruses in the environment. In: Goyal SM, editor. Viruses in foods. Boston: Springer;2006. p.151-87.

5. Sobsey MD, Meschke JS. Virus survival in the environment with special attention to survival in sewage droplets and other environmental media of fecal or respiratory origin: report for the World Health Organisation. Geneva: WHO; 2003.

6. Flores EF, organizadora. Virologia veterinária. $2^{\mathrm{a}}$ ed rev aum. Santa Maria: UFSM; 2012.

7. Devera R, Blanco Y, Hernández H, Simoes D. Toxocara spp. y otros helmintos en plazas y parques de Ciudad Bolívar, estado Bolívar (Venezuela). Enferm Infecc Microbiol Clin. 2008;26:23-6.

8. Guimarães AM, Alves EG, Rezende GF, Rodrigues MC. Ovos de Toxocara sp. e larvas de Ancylostoma sp. em praça pública de Lavras, MG. Rev Saude Publica. 2005;39:293-5.

9. Nooraldeen K. Contamination of public squares and parks with parasites in Erbil city, Iraq. Ann Agric Environ Med. 2015;22:418-20.

10. Otero D, Alho AM, Nijsse R, Roelfsema J, Overgaauw P, Madeira de Carvalho L. Environmental contamination with Toxocara spp. eggs in public parks and playground sandpits of Greater Lisbon, Portugal. J Infect Public Health. 2018;11:94-8.

11. Prestes LF, Jeske S, Santos CV, Gallo MC, Villela MM. Contaminação do solo por geohelmintos em áreas públicas de recreação em municípios do sul do Rio Grande do Sul (RS), Brasil. Rev Patol Trop. 2015;44:155-62.

12. Neves DP, Melo AL, Linardi PM, Vitor RW. Parasitologia humana. $11^{\mathrm{a}}$ ed. São Paulo: Atheneu; 2005.

13. Staggemeier R, Bortoluzzi M, Silva Heck TM, Silva T, Spilki FR, Matos Almeida SE. Molecular detection of human adenovirus in sediment using a direct detection method compared to the classical polyethylene glycol precipitation. J Virol Methods. 2015;213:65-7.

14. Monteiro GS, Fleck JD, Kluge M, Rech NK, Soliman MC, Staggemeier R, et al. Adenoviruses of canine and human origins in stool samples from free-living pampas foxes (Lycalopex gymnocercus) and crab-eating foxes (Cerdocyon thous) in Sao Francisco de Paula, Rio dos Sinos basin. Braz J Biol. 2015;75 Suppl:11-6.

15. Buonavoglia C, Martella V, Pratelli A, Tempesta M, Cavalli A, Buonavoglia D, et al. Evidence for evolution of canine parvovirus type 2 in Italy. J Gen Virol. 2001;82:3021-5.

16. Li Y, Ge X, Zhang H, Zhou P, Zhu Y, Zhang Y, et al. Host range, prevalence, and genetic diversity of adenoviruses in bats. J Virol. 2010;84:3889-97.

17. Tavalla M, Oormazdi H, Akhlaghi L, Razmjou E, Lakeh MM, Shojaee S, et al. Prevalence of parasites in soil samples in Tehran public places. Afr J Biotechnol. 2012;11:4575-8.

18. Mandarino-Pereira A, Souza FS, Lopes CW, Pereira MJ. Prevalence of parasites in soil and dog feces according to diagnostic tests. Vet Parasitol. 2010;170:176-81.

19. Tudor P. Soil contamination with canine intestinal parasites eggs in the parks and shelter dogs from Bucharest area. Agric Agric Scie Procedia. 2015;6:387-91.

20. Vargas MM, De Bastiani M, Ferreira JR, Calil LN, Spalding SM. Frequência de estruturas parasitárias em praças e parques públicos da cidade de Porto Alegre-RS. Rev Patol Trop. 2013;42:434-42.

21. Centers for Disease Control and Prevention. Hookworm (intestinal). [cited 2019 Feb 1] Available from: https://www. cdc.gov/dpdx/hookworm/index.html

22. Centers for Disease Control and Prevention. Toxocariasis. [cited 2019 Feb 1] Available from: https://www.cdc.gov/dpdx/ toxocariasis/index.html

23. Kluge M, Fleck JD, Soliman MC, Luz RB, Fabres RB, Comerlato $\mathrm{J}$, et al. Human adenovirus (HAdV), human enterovirus (hEV), and genogroup A rotavirus (GARV) in tap water in southern Brazil. J Water Health. 2014;12:526-32.

24. Girardi V, Demoliner M, Rigotto C, Schneider VE, Paesi S, Spilki FR. Assessment of diversity of adenovirus DNA polymerase gene in recreational waters facilitated by ultracentrifugal concentration. J Water Health. 2018;16:102-11.

25. Iaconelli M, Valdazo-González B, Equestre M, Ciccaglione AR, Marcantonio C, Della Libera S, et al. Molecular characterization of human adenoviruses in urban wastewaters 
using next generation and Sanger sequencing. Water Res. 2017;121:240-7.

26. Hewitt J, Greening GE, Leonard M, Lewis GD. Evaluation of human adenovirus and human polyomavirus as indicators of human sewage contamination in the aquatic environment. Water Res. 2013;47:6750-61.

27. Wieczorek M, Krzystoszek A, Witek A. Species-specific identification of human adenoviruses in sewage. Pol J Microbiol. 2015;64:23-8
28. Schwarz KR, Sidhu JP, Pritchard DL, Li Y, Toze S. Decay of enteric microorganisms in biosolids-amended soil under wheat (Triticum aestivum) cultivation. Water Res. 2014;59:185-97.

29. Fongaro G, García-González MC, Hernández M, Kunz A, Barardi CR, Rodríguez-Lázaro D. Different behavior of enteric bacteria and viruses in clay and sandy soils after biofertilization with swine digestate. Front Microbiol. 2017;8:74. 